\title{
Adversarial Framing: President Bashar al-Assad's Depiction of the Armed Syrian Opposition
}

\section{by Fabien Merz}

\section{$(\mathrm{cc}) \mathrm{BY}$}

This work is licensed under a Creative Commons Attribution 3.0 License.

\section{Abstract}

This paper evaluates how Syrian president Bashar al-Assad is framing his opponents in the context of the Syrian civil war. The question is addressed by conducting a qualitative thematic analysis of 13 interviews he gave to international television news networks and newspapers between March and November 2013. It is found that Al-Assad consequently labels the armed opposition as "terrorists" preponderantly composed of groups affiliated to Al-Qaeda. The "terrorists" are framed as posing a threat to the region as well as to international security on a global scale. Furthermore, Al-Assad denies the armed opposition its Syrian grassroots by portraying them as outside aggressors fighting for foreign interests. They are also depicted as "enemies of the Syrian people", responsible for all the atrocities and human suffering committed during the Syrian civil war.

Keywords: Syria; Syrian civil war; Bashar al-Assad; framing; adversarial framing; Syrian opposition; terrorism; thematic network analysis.

\section{Introduction $^{1}$}

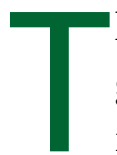

he Syrian Crisis is the armed conflict in Syria between forces loyal to President Bashar al-Assad's government and those seeking to oust it. The unrest began with several anti-government protests initiated in the beginning of 2011 within the wider context of the protest movements known as the Arab Spring (Sterling, 2012). After several government crackdowns (Human Rights Watch, 2011), the protests evolved into an armed rebellion, which since mid 2012, was considered by the United Nations to be a full-scale civil war (Charbonneau and Evans, 2012).

During the conflict, President Al-Assad framed the armed Syrian opposition through interviews he gave to international media. In this context, it is interesting to evaluate how Al-Assad portrayed his opponents. Specifically, one could ask: How did President Bashar al-Assad frame the armed Syrian opposition in his 2013 media interviews? As Al-Assad gave these interviews to international medias, his narrative is primarily intended for the international public opinion. This means that the subsequently analysed narrative of Al-Assad must be considered to be primarily predetermined for an international audience and not for a domestic, Syrian one. It is furthermore important to note that the aim of this paper is not to offer an objective characterisation of the Syrian opposition, but to focus on how it was framed by President Al-Assad.

\section{Literature review}

The works of Robert Entman $(1991,1993,2003)$ are particularly useful in order to better understand the concept of political framing. According to him, "successful political communication requires the framing of events, issues and actors in ways that promote perceptions and interpretations that benefit one side while hindering the other" (Entman, 2003, p. 414). The mechanism of framing entails the selection of certain facts 


\section{Journal of Terrorism Research}

and aspects of reality in order to make them more salient (Entman, 1993). This is achieved through frequent references, repetition, and associations with culturally familiar symbols. Framing also calls attention to some aspects of reality while obscuring other elements (Entman, 1993). A particular frame does not eliminate all inconsistent information but the words and images that comprise a frame are repeatedly reinforced through associations with each other in order to render one basic interpretation more readily comprehensive and memorable than others (Entmann, 1991). Entman further asserts, "those frames that employ more culturally resonant terms have the greatest potential for influence" (2003, p. 417).

When it comes to adversarial framing in the context of a violent conflict, terms such as "terrorism" or "terrorist" have a great potential for influence. Aside from being culturally resonant (Nagar, 2010), they also carry strong condemnatory and pejorative connotations (Hoffman, 2006; English, 2009). Some would even argue that "terrorism" is probably the most powerful condemnatory word in the English language (Guelke, 1998).

Anais Chagankerian (2013) has taken into account the effectiveness of the "terrorism" label in delegitimizing those stamped with it. She argues that due to the lack of a commonly accepted definition of what terrorism actually is, governments and political actors are free to use the word as they see fit. Therefore, actions become terrorism and groups become terrorists when it is seen judicious to label them as such (Chagankerian, 2013). The delegitimizing impact on those to whom the "terrorist" label is applied comes from its profoundly pejorative connotation and its emotional impact, i.e., referring to an actor as a terrorist implies instilling fear regarding his actions and motives (Chagankerian, 2013).

Chagankerian (2013) concludes that the "terrorist" label becomes a very strong strategic tool in order to delegitimize political opponents due to the lack of a commonly accepted definition and the profound pejorative connotations of the word.

Keeping in mind that there might be variations in regards to how the term "terrorism" is understood in different cultural settings, it is, notwithstanding, generally considered to have strongly negative connotations (Hoffman, 2006; English, 2009; Chagankerian, 2013). In these regards, it is also important to note that those labelled by their adversaries as terrorists hardly ever refer to themselves as such, but rather use other terms such as freedom fighters, resistants, separatists, guerrilleros, etc. (Whittaker, 2003; Hoffman, 2006). ${ }^{2}$

This is may be best exemplified by Yasser Arafat's famous speech before the United Nations General Assembly in which he drew a clear distinction between terrorists on one side and revolutionaries that fight for a just cause on the other. Arafat took great care to disassociate the PLO from the terrorist label while asserting and emphasising its role as legitimately fighting for freedom; i.e., he portrays the members of his organisation as freedom fighters (Monde Diplomatique, 1974).

Considering its cultural significance and delegitimizing power, the "terrorist" label is unsurprisingly often used in order to frame adversaries negatively. In her 2010 article "Framing Separatism as Terrorism: Lessons from Kosovo", Elena Pokalova brings the concepts of "terrorism" and "framing" together by considering how separatists are framed as terrorists by governments.

She argues that since September 11, 2001, governments worldwide are presented with the opportunity to portray their internal adversaries as being part of the international terrorist threat (Pokalova, 2010). This allows governments to disguise and dismiss the causes and grievances of their adversaries through references to an imminent terrorist threat (Pokalova, 2010). This framing of separatists as terrorists, therefore, enables the government to choose from a wide range of repressive measures without fearing international 


\section{Journal of Terrorism Research}

condemnation and prevents international pressure for a settlement of the conflict by political means (Pokalova, 2010).

Applied to the Syrian context, the theoretical overview considered above makes it very probable that Syrian President Bashar al-Assad will try to frame his opponents negatively (Entman, 1991, 1993, 2003; Pokalova, 2010). While his government is involved in a violent conflict, it is also probable that he will do so by using the condemnatory and delegitimizing power of the "terrorist" label (English, 2009; Nagar, 2010; Chagankerian, 2013). As exemplified by Chagankerian (2013) and Pokalova (2010) the rationale behind this behavioural pattern is aimed at delegitimizing the opposition while legitimising actions taken by the Syrian government against them.

\section{Methodology}

The data for the analysis of how the Syrian opposition is framed is composed of 13 interviews that President Al-Assad gave to television news networks and newspapers from 10 different countries between March and November 2013 (see Appendix 1 for a comprehensive list of interviews).

Each interview was already transcribed either by the media agency, which conducted it, or by the Syrian Arab News Agency (SANA). As SANA is government-owned, and as the Syrian government is one of the belligerent parties, there was a potential risk with regard to the credibility of the transcripts provided by SANA. Therefore, the transcripts from the SANA news agency were checked with particular care against video recordings of the interviews (see appendix 1 for the sources of the transcripts). These interviews that were conducted in languages other than English were available in translated transcriptions and were checked against other translated transcriptions or English dubbed video recordings of the interviews. It is important to note that no major discrepancies were found in this process of cross-comparison.

The year 2013 was chosen as the timeframe because it was the first year since the beginning of the Syrian conflict in which President Al-Assad gave enough interviews to enable the gathering of sufficient data.

In order to show how President Al-Assad framed the armed Syrian opposition, the gathered data was analysed by using a thematic analysis aided by a thematic network, as proposed by Jennifer Attride-Stirling (2001). A thematic analysis seeks to identify the most salient themes in a text whereas the thematic network is used to facilitate the structuring of these themes by offering a powerful organisation principle. In addition, the thematic network serves as an illustrative tool, which helps the researcher in his interpretation and the reader in his understanding of the analysis (Attride-Stirling, 2001).

Entman has stated that: "researchers identify frames by investigating specific words and pictures that consistently appear in a narrative and convey thematically constant meanings across media and time" (1991, p. 7). As a thematic analysis seeks to: "unearth the themes salient in a text" (Attride-Stirling, 2001, p. 387), this method of analysis seems perfectly suited to identifying how President Al-Assad framed the Syrian opposition.

\section{Analysis}

\section{Construction of the thematic network}

Instead of solely focusing the coding process of the thematic analysis on parts relevant to the armed 


\section{Journal of Terrorism Research}

opposition, it was decided that a broader perspective was needed; thus, everything that was related to the Syrian opposition as a whole was coded. The aim of doing this was to generate a comprehensive thematic network representing the whole opposition as President Al-Assad depicted it. The overview of the depicted opposition landscape was then used to better direct the focus of the subsequent analysis on themes that are really relevant to the research question. The detailed analysis itself is therefore solely focused on how the armed Syrian opposition is framed.

A total of 195 initial codes were generated inductively. They emerged from the interaction with relevant data, i.e., the codes were what Robson (2011) calls "data driven". These initial codes were then regrouped into what Attride-Stirlinge (2001) calls basic themes or what is more commonly known simply as themes (Ryan and Bernard, 2003; Robson, 2011). The 195 initial codes were regrouped into a total of 10 basic themes (see Appendix 2).

The 10 basic themes were then further regrouped into what Attride-Stirling (2001) calls organizing themes. These organizing themes basically summarize the principal assumption about a group of similar basic themes and reveal the salient parts of the data at a higher level of abstraction from the text (Attride-Stirlinge, 2001). The regrouping of the 10 basic themes resulted in three organizing themes. Each one of these organizing themes represents how President Al-Assad framed a particular part of the opposition, i.e., the armed opposition within Syria, the political (unarmed) opposition within Syria, and the Syrian opposition abroad. Indeed, President Al-Assad made a very clear distinction between those three parts of the opposition. This distinction can be found throughout the interviews. For example, President Al-Assad, in his interview with the Sunday Times in March 2013, states:

If you want to talk about the opposition, there is another misconception in the West. They put all the entities even if they are not homogeneous in one basket. We have to be clear about this. We have opposition that are political entities and we have armed terrorists (Sunday Times, 2013, paragraph 14).

Al-Assad particularly emphasises the importance of distinguishing between political (unarmed) opposition and armed terrorists. He further repeatedly talks about the unarmed opposition in Syria and the exiled Syrian opposition as being distinct from each other. In the interview Al-Assad gave the Frankfurter Allgemeine Zeitung in June 2013, this distinction becomes particularly apparent:

The oppositional groups abroad are reporting to Western foreign ministries and their intelligence organizations. [...] To be considered a genuine oppositional force, one must live in Syria with the Syrian people and experience its problems and difficulties. Only then can this opposition be a part of the political process (Frankfurter Allgemeine Zeitung, 2013, paragraph 48).

It is also important to note that Al-Assad consistently labels the armed groups fighting against the government inside Syria as "terrorists". This is well illustrated in a passage from the Rai News interview Al-Assad gave in September 2013, where he explains the distinction between what he considers political opposition and what terrorism:

Opposition is a political entity, is a political program, is a political vision; this is opposition. If you have arms and destroy and kill and assassinate, this is not opposition. This is what you call terrorism all over the world and in every other country (Rai News, 2013, paragraph 16).

This depiction of the armed Syrian opposition as terrorists is found as a constant narrative throughout all the analysed interviews. The overall Syrian opposition as depicted by President Al-Assad can, therefore, be considered as being composed of terrorists operating in Syria, a political (unarmed) opposition within Syria, 


\section{Journal of Terrorism Research}

and a political opposition abroad. These are the three organizing themes of the thematic network proposed.

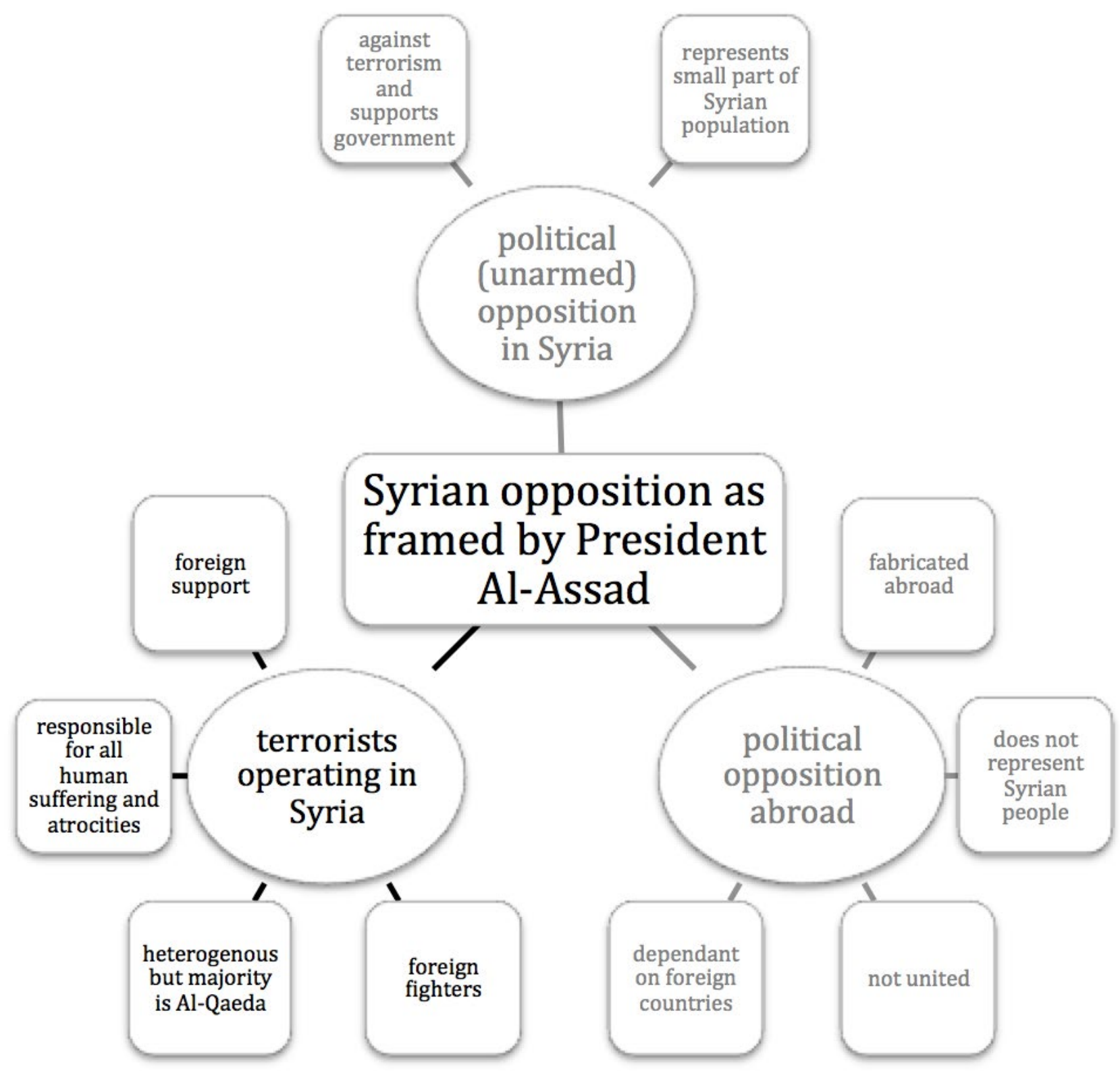

Figure 1: Thematic network of the Syrian opposition as framed by President Al-Assad.

As proposed by Attride-Stirling (2001), this thematic network uses three levels of themes, which is illustrated in Figure 1. The global theme represents the Syrian opposition as a whole. The three organizing themes represent the distinction Al-Assad makes between the political opposition in Syria, the political opposition abroad, and the terrorists operating in Syria. Each of the 10 basic themes represents an element of the frame Al-Assad uses to define the opposition; they are clustered around the part of the opposition to which they relate in Figure 1.

As seen above, Al-Assad frames the armed opposition within Syria as "terrorists". Therefore, to answer the research question, the analysis will focus on the organizing theme terrorists operating in Syria as well as on its four constituent basic themes: (1) foreign support; (2) responsibility for all human suffering and atrocities; (3) heterogeneity, but majority affiliated with Al-Qaeda; (4) foreign fighters. 


\section{Journal of Terrorism Research}

\section{Analysis of how the armed Syrian opposition is framed by President Al-Assad}

In order to deconstruct how the armed Syrian opposition is framed, besides being labelled as "terrorists", each of the four basic themes linked to the armed opposition will be analysed separately.

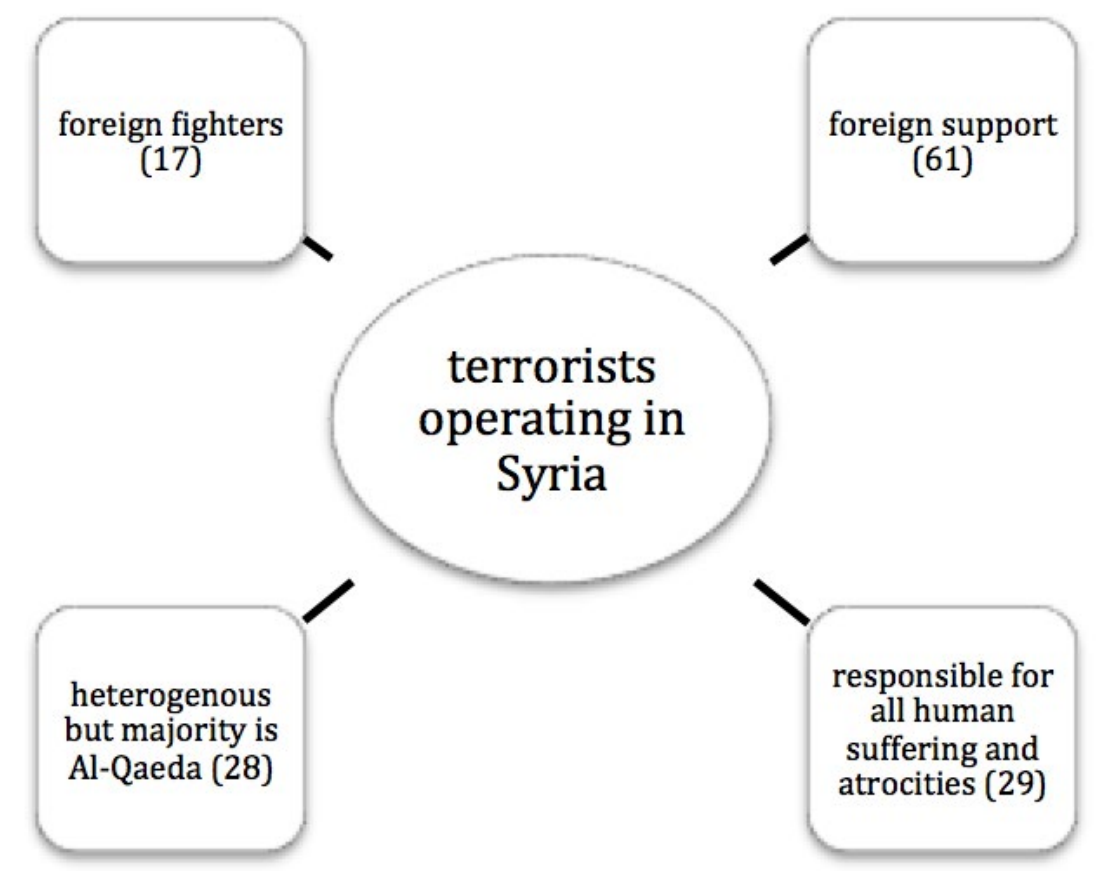

Figure 2: Organizing theme: The armed Syrian opposition framed as terrorists operating in Syria. Note: the numbers in the brackets represent the number of initial codes attributed to each basic theme as a raw estimation of their importance in the frame.

The number of initial codes attributed to each basic theme provides an overview of which elements were the most used and referred to throughout President Al-Assad's narrative (see figure 2). As frames work by making some elements more salient by constantly repeating and making reference to them (Entman, 1991), these numbers give an estimation of which elements were the most salient in the frame used. This serves as an overview of which elements of the different organizing themes were most emphasized in Al-Assad's narrative.

\section{Basic theme: Foreign support}

A total of 61 initial codes were related to the foreign support of terrorists. This indicates the emphasis President Al-Assad put on the implication of non-domestic actors in the Syrian conflict. He repeatedly accuses (especially, but not exclusively) Turkey, Saudi Arabia, and Qatar of providing direct support in the form of funding, armament, and logistical aid to the terrorists. The Western countries (USA, UK, and France named explicitly) are accused of supporting the terrorists indirectly with political support and intelligence.

What is interesting is that Al-Assad goes further than just asserting that the terrorists receive direct support from foreign countries. At certain points, he very clearly claims that the armed groups are not only supported, but also controlled by foreign countries. For example, in the interview Al-Assad gave the Sunday Times in March 2013, he asserts the control Turkey, Saudi Arabia, and Qatar exercise on the groups they support:

Yes there are many groups as I have said with no leadership, but we know that their real leadership 


\section{Journal of Terrorism Research}

are those countries that are funding and supplying their weapons and armaments-mainly Turkey, Qatar and Saudi Arabia (Sunday Times, 2013, paragraph 27).

Those groups are, therefore, pictured as terrorist proxies following orders and fighting on behalf of foreign powers. This implies that these different groups do not fight for the interests of the Syrian people or because of domestic causes, but for the interest of those foreign countries that support, finance, and ultimately control them.

This argument regarding foreign powers intervening in Syria has also to be seen in the light of the larger regional conflict, which opposes predominantly Sunni Saudi Arabia and Qatar to largely Shia Iran. Within this larger context, Iran supports the regime of Bashar al-Assad (Fulton, 2013), while Saudi Arabia and Qatar support the Sunni-dominated parts of the opposition (Khalaf and Fielding-Smith, 2013). Bearing this in mind, it becomes self-explaining as to why Al-Assad accuses the terrorist groups of fighting as proxies of Saudi-Arabia, Qatar, and other predominately Sunni regional powers such as Turkey.

By asserting that the armed Syrian opposition is contracted from outside, Al-Assad portrays the Syrian conflict not as an internal struggle, but as a foreign aggression. In the interview he gave to the Spiegel in October 2013, when asked about the reason for the conflict, Al-Assad immediately asserts that the conflict raging in Syria is external in origin: "My answer here has to be frank and straight to the point. This conflict has been brought to our country from abroad“ (Der Spiegel, 2013, paragraph 16). The assertion that the Syrian conflict is caused by foreigners implies that the root causes of the conflict do not stem from the grievances of the Syrian population. It further suggests that the Syrian government is protecting Syria and its population from foreign aggression.

In this depiction, as the conflict in Syria originated abroad, the solution to it also primarily has to be found abroad. From this perspective, the conflict would end with the cessation of foreign interference. In the interview he gave in September 2013 to Le Figaro, when asked how the war in Syria could be stopped, President Al-Assad had an astonishingly simple solution:

So in response to your question, the solution today lies in stopping the influx of terrorists into Syria and stopping the financial, military or any other support they receive (Le Figaro, 2013, paragraph 47).

He also depicts a very clear hierarchical structure of the "enemies of the Syrian people". At the bottom of the hierarchy are the terrorist groups operating in Syria, who mainly act as proxies of certain Arab states such as Saudi Arabia and Qatar, as well as regional powers such as Turkey. These Arab states and regional powers are themselves what Al-Assad calls "underlings" and "lackeys" of the great Western powers such as the United States, Great Britain, and France. Ultimately, as framed by Al-Assad, the different groups fighting against the Syrian government are, therefore, will-less proxies fighting for the interest of regional powers who are themselves dependent and obedient towards the United States, Great Britain, and France.

\section{Basic theme: Responsibility for all the human suffering and committed atrocities}

A total of 29 initial codes were related to the human suffering and the atrocities caused by the terrorists. This indicates how much emphasis is also put on blaming the armed opposition for the suffering that the Syrian population had to endure during the conflict.

According to Al-Assad, the vast majority of displaced civilians fled because of the threat posed by the terrorists. In the Fox News interview Al-Assad gave in September 2013, when questioned about the millions of Syrian refugees, he stressed that the terrorists were responsible for the displaced Syrians: 


\section{Journal of Terrorism Research}

Whenever the terrorists enter an area, the civilians would leave unless they use them as human shields, but in most of the cases the civilians would quit their area because of the terrorists, and that's why you have so many refugees (Fox News, 2013, paragraph 158).

Al-Assad further accused the terrorists of using civilians as human shields and of deliberately infiltrating residential areas in order to cause civilian causalities and then blaming the Syrian Army for the result. When the interviewer from Fox News asked Al-Assad about the attacks launched by the Syrian army and about the civilians killed as a result of them, he very clearly put the blame for those collateral damages on the terrorists:

[...] when the terrorists infiltrate residential areas in villages and sometimes in the suburbs of the cities, and within large cities, and the army has to go there to get rid of those terrorists. The army should defend the civilians, not the opposite. You cannot leave the terrorists free, killing the people, assassinating the people, beheading the people and eating their hearts. When we go to defend them, you say you are killing your own people! You don't, but in every war, you have casualties (Fox News, 2013, paragraph 114).

From the statement above, it can further be perceived that the "terrorists" are also accused of committing all kinds of atrocities, ranging from beheadings to cannibalism. It is not surprising that besides being blamed for displacing millions of Syrians, using civilians as human shields, and committing atrocities, the "terrorists" are also accused of having committed various massacres, including multiple chemical weapon attacks. For example, Al-Assad explicitly blames them for carrying out the chemical attack of March 19, 2013 in Khan al-Asal near Aleppo (TeleSUR, 2013, paragraph 38; Russia 24 TV, 2013, paragraph 16). It is also interesting to note that Al-Assad implies that the "terrorists" were either able to produce the chemical agents themselves"Sarin gas is called kitchen gas because anyone can make it" (Fox News, 2013, paragraph 82) —or that it was provided to them by a foreign country:

[...] the reality is that the West and particular countries in the region, including Turkey and Saudi Arabia, maintain direct contact with the terrorists and supply them with all measure of arms. We believe that one of these countries has supplied the terrorists with chemical weapons (Russia $24 \mathrm{TV}$, 2013, paragraph 20).

This accusation inevitably also refers to the foreign support part of the frame. To recapitulate, the "terrorists" are represented as the enemies of the Syrian people, responsible for all the woes that have afflicted Syria and its population since the beginning of the conflict. Al-Assad, therefore, frames the armed Syrian opposition as being the epitome of evil, barbarism, and inhumanity.

\section{Basic Theme: Heterogeneous groups but the majority is affiliated with Al-Qaeda}

A total of 28 initial codes were related to issues regarding the composition of the armed Syrian opposition. Al-Assad acknowledges that his military adversaries cannot be considered a monolithic bloc. He affirms that a minority of them are composed of individuals such as criminals and mercenaries who are fighting for financial advantages and do not have any political or ideological motivations whatsoever. In the Sunday Times interview he gave in March 2013, Al-Assad describes this minority amongst his adversaries:

The spectrum ranges from petty criminals, drug dealers, groups that are killing and kidnapping just for money to mercenaries and militants; these clearly do not have any political agenda or any ideological motivations (Sunday Times, 2013, paragraph 22).

In the same Sunday Times interview, Al-Assad goes on to link those criminals and mercenaries described above to the Free Syrian Army: 
The so-called "Free Army" is not an entity, as the West would like your readers to believe. It is hundreds of small groups [...] there is no entity, there is no leadership, there is no hierarchy; it is a group of different gangs working for different reasons. The Free Syrian Army is just the headline, the umbrella that is used to legitimize these groups (Sunday Times, 2013, paragraph 23).

However, according to Al-Assad, those "gangs" operating under the umbrella of what is called the Free Syrian Army are just a minority. He describes the vast majority of the "terrorists" as religious extremists affiliated with Al-Qaeda and its offshoots, like the Nusra Front. In the interview he gave to Le Figaro on September 3, 2013 he asserts that, "today we are fighting terrorists, 80-90\% of them affiliated to Al-Qaeda" (Le Figaro, 2013, paragraph 47). When Al-Assad is challenged by the Fox News interviewer later in September on these numbers and confronted with estimations that put the percentage of jihadists linked to Al-Qaeda significantly lower, he dismisses them, saying:

No one has these precise numbers. [...] It is difficult to be precise, you don't have clear and precise data. What I can tell you is 80 to $90 \%$ of the rebels or terrorists on the ground are Al Qaeda and their offshoots (Fox News, 2013, paragraph 97).

He accuses Al-Qaeda and its affiliated groups of infiltrating Syrian society with their extremist ideology. Their final objective, however, is to spread their ideology all over the world, as Al-Assad asserts in the RT News interview he gave in November 2013: "their final aim is to have this, let's say, Islamic Emirate in Syria where they can promote their own ideology in the rest of the world" (RT News, 2013, paragraph 71).

This is particularly interesting, as by emphasising the international agenda Al-Qaeda and its offshoots pursue in Syria, Al-Assad frames the terrorists operating in Syria as a potential threat, not only for the region, but also for the rest of the world. Al-Assad implies that, if his regime were to lose the war, Syria would become a safe haven for Al-Qaeda and its affiliates with catastrophic repercussions for the neighbouring countries and the interests of Western countries in the region, as well as for security on a global scale.

\section{Basic theme: Foreign fighters}

With a total of 17 initial codes, the implication of foreign fighters in the Syrian conflict was the least emphasised theme in Al-Assad's narrative. He claims that the Syrian army is fighting "terrorists from over 80 countries who are supported by Western and Arab states” (Le Figaro, 2013, paragraph 70).

This basic theme is closely related and partially overlaps with the foreign support theme. Al-Assad accuses his neighbours (especially Turkey) of harbouring foreign fighters and helping them to cross into Syria. In the interview he gave the Turkish Ulusal TV network in April 2013, he asserts that: “Terrorists are entering Syria in their thousands, and maybe in tens of thousands" (paragraph 17). For him, it is therefore clear that: "At the end, large numbers of them [terrorists] are foreigners, not Syrians" (Fox News, 2013, paragraph 205).

The narrative that those fighting against the government are to a large part not Syrians fighting for domestic causes, but foreigners fighting in the interests of foreign powers reinforces the argument that the conflict is caused and maintained from abroad.

\section{Discussion and Conclusion}

As frames promote perceptions and interpretations that benefit one side while hindering the other (Entman, 2003), it was expected that President Al-Assad would frame the armed Syrian opposition in a negative way. In the 13 interviews analysed, Al-Assad meets that expectation by consequently attaching the "terrorist" label 


\section{Journal of Terrorism Research}

to the armed Syrian opposition. Al-Assad extensively uses the pejorative and condemnatory power of the "terrorists" label in order to delegitimize the armed opposition and to present his government as legitimately fighting them to the eyes of the international public opinion (Pokalova, 2010, Chagankerian, 2013).

What is less anticipated and becomes apparent only at a closer analysis of Al-Assad's narrative is that he also extensively uses other elements in order to frame the armed opposition negatively. These elements are repeatedly placed and reinforced through association with each other throughout the narrative presented by Al-Assad. In addition to the "terrorist" label, these elements also have to be considered as important parts of Al-Assad's framing of the Syrian opposition.

The armed opposition is continually depicted as foreign controlled proxies preponderantly composed of foreign fighters who are waging war in Syria for foreign interests. It can be said that Al-Assad denies the armed opposition its Syrian grassroots and frames them either as outside aggressors or as mere servants of foreign interests. By asserting that $80-90 \%$ of the rebels are affiliated to Al-Qaeda or their offshoots and by emphasizing their international agenda, he also undeniably frames the armed Syrian opposition as posing not only a regional but also a potentially global threat.

The armed opposition is further portrayed as being the cause of all the human suffering and as the perpetrators of all the atrocities committed in Syria. Al-Assad, therefore, clearly frames the armed Syrian opposition as being the "enemy of the Syrian people" representing the epitome of evil, barbarism and inhumanity.

By deconstructing Al-Assad's narrative about the armed Syrian opposition, this paper shows how and to a certain extend why the Syrian President frames his adversaries negatively in the context of the Syrian Civil War. It would have been interesting to incorporate and offer an objective characterization that could be compared against the depiction of the armed Syrian opposition presented by Al-Assad. However, the events in Syria are ongoing at the time of writing this paper, the circumstances on the ground rapidly changing, and facts often distorted by propaganda. All these make it difficult to offer an objective picture of the opposition at the present time. A genuine and objective "reality check" that can be compared against the frame used by Al-Assad will therefore need more time in order to allow, what Carl von Clausewitz (1832/1984) famously called the "fog of war" to fade away.

\section{About the author: Fabien Merz is a Masters student at the Centre for the Study of Terrorism and Political} Violence, University of St. Andrews. He holds a Bachelor degree in International Relations from the University of Geneva.

\footnotetext{
Notes

1. I especially want to thank Dr. Sarah Marsden for her guidance and support throughout the writing and publishing process. My thanks also go to the two anonymous reviewers, who provided insightful comments on how to improve an earlier version of this paper.

2. As Richard English (2009) notes, there are a few exceptions in which persons have applied the term "terrorists" to themselves and their associates. IRA member Pedar O'Donell, for example, used the term "terrorism" to refer to British repression as well as to IRA activity. Osama bin Laden has, for his part, spoken of good and bad terrorism, claiming that Al-Qaeda was practicing the former while its adversaries were carrying out the latter.
}

\section{References}

Attride-Stirling, J. (2001). Thematic networks: an analytic tool for qualitative research. Qualitative Research, 1:3, 385-405. 


\section{Journal of Terrorism Research}

Chagankerian, A. (2013, July 18). The Delegitimizing Power of the "Terrorism" Label. e-International Relations. Retrieved December 15, 2013, from http://www.e-ir.info/2013/07/18/the-delegitimizing-power-ofthe-terrorism-label/

Charbonneau, L. \& Evans, D. (2012, June 12). Syria in civil war, UN official says. Reuters. Retrieved December 15, 2013 from http://uk.reuters.com/article/2012/06/12/uk-syria-crisis-idUKBRE84S0P320120612

Der Spiegel. (2013, October 7). Interview with Bashar Assad: In the End, a Lie is a Lie. Germany. Transcript retrieved on December 12, 2013 from http://www.spiegel.de/international/world/spiegel-interview-withsyrian-president-bashar-assad-a-926456.html

English, R. (2009). Terrorism: How to respond. Oxford: Oxford University Press.

Entman, R. M. (1991). Framing U.S. Coverage of International News: Contrasts in Narratives of the KAL and the Iran Air Incidents. Journal of Communication, 41:4, 6-27.

Entman, R. M. (1993). Framing: Toward Clarification of a Fractured Paradigm. Journal of Communication, $43: 4,51-58$.

Entman, R. M. (2003). Cascading Activation: Contesting the White House's Frame After 9/11. Political Communication, 20:4, 415-432.

Fox News. (2013, September 17). Interview with Syrian President Bashar al-Assad. USA. Transcript retrieved on December 12, 2013 from http://www.globalresearch.ca/president-bashar-al-assads-interview-on-syriaschemical-weapons-transcript/5350429

Frankfurter Allgemeine Zeitung. (2013, June 17). F.A.Z.-Interview with Bashar al-Assad: "Europe's backyard would become a terrorist haven". Germany. Transcript retrieved on December 12, 2013 from http://www.faz. net/aktuell/politik/ausland/naher-osten/f-a-Z-interview-with-bashar-al-assad-europe-s-backyard-wouldbecome-a-terrorist-haven-12225367.html

Fulton, W. \& Holliday, J. \& Wyer, S. (2013). A Joint Report By AEI'S Critical Threats Project \& Institute For The Study Of War: Iranian Strategy In Syria. Retrieved on March 31, 2014 from http://www.understandingwar. org/report/iranian-strategy-syria

Guelke, A. (1998). The Age of Terrorism and the International Political System. London: I. B. Tauris.

Hoffman, B. (2006). Inside terrorism. New York, NY: Columbia University Press.

Human Rights Watch. (2011, June 1). We've Never Seen Such Horror. Retrieved December 15, 2013, from http://www.hrw.org/node/99345/section/5

Khalaf, R. \& Fieldin-Smith, A. (2013). Qatar bankrolls Syrian revolt with cash and arms. Financial Times. Retrieved on March 31, 2014 from http://www.ft.com/intl/cms/s/0/86e3f28e-be3a-11e2-bb35-00144feab7de. html\#axzz2xYySpdt5

Le Figaro. (2013, September 7). Interview with Syrian President Bashar al-Assad. France. Transcript retrieved on December 12, 2013 from http://syria360.wordpress.com/2013/09/03/president-assads-interview-with-lefigaro/

Le Monde diplomatique (1974). Arafat's Speech at UN General Assembly. Retrieved on March 28, 2014 from http://www.monde-diplomatique.fr/cahier/proche-orient/arafat74-en

Nagar, N. (2010). Who is Afraid of the T-word? Labeling Terror in the Media Coverage of Political Violence Before and After 9/11. Studies in Conflict \& Terrorism, 33:6, 533-547. 


\section{Journal of Terrorism Research}

Pokalova, E. (2010). Framing Separatism as Terrorism: Lessons from Kosovo. Studies in Conflict \& Terrorism, $33: 5,429-447$.

Rai News 24. (2013, September 29). Syria President al-Assad Interview: "We focus today on getting rid of terrorists and their ideology". Italy. Transcript retrieved on December 12, 2013 from http://www. globalresearch.ca/president-al-assad-interview-we-focus-today-on-getting-rid-of-terrorists-and-theirideology/5352063

Robson, C. (2011). Real World Research. Chichester: John Wiley \& Sons Ltd.

RT News. (2013, November 11). I'm not Western puppet - I live and die in Syria. Russia. Transcript retrieved on December 12, 2013 from http://rt.com/news/assad-interview-exclusive-syria-265/

Russia 24 TV. (2013, September 24). Interview with Syrian President Bashar al-Assad. Russia. Transcript translated into English retrieved on December 12, 2013 from http://www.globalresearch.ca/syria-presidentbashar-al-assad-interview-on-chemical-weapons/5349664

Ryan, G. W. \& Bernard, H. R. (2003). Techniques to identify themes. Field Methods, 15, 85-109.

Sterling, J. (2012, March 1). Daraa: The Spark that lit the Syrian flame. CNN. Retrieved December 15, 2013, from http://edition.cnn.com/2012/03/01/world/meast/syria-crisis-beginnings/index.html

Sunday Times. (2013, March 3). Interview with Syrian President Bashar al-Assad. United Kingdom. Transcript retrieved on December 13, 2013 from http://syria360.wordpress.com/2013/03/03/president-assads-interviewwith-sunday-times/

Sunday Times. (2013, March 3). Interview with Syrian President Bashar al-Assad. United Kingdom. Transcript retrieved on December 13, 2013 from

http://syria360.wordpress.com/2013/03/03/president-assads-interview-with-sunday-times/

Tele SUR. (2013, September 25). President al-Assad interview with tele SUR TV: US Policy has been based on Lies since the beginning. Venezuela. Transcript translated into English retrieved on December 12, 2013 from http://www.globalresearch.ca/president-al-assad-interview-with-telesur-tv-us-policy-has-been-based-onlies-since-the-beginning/5351660

Ulusal Kanal. (2013 April 5). Bashar Al Assad Interview: "Foreign Powers are Supporting the Entry of Terrorists in Syria". Turkey. Transcript translated into English retrieved on December 12, 2013 from http://syria360. wordpress.com/2013/04/05/president-bashar-al-assads-full-interview-with-turkish-tv/

Von Clausewitz, C. (1984). On War. (Howard, M. \& Paret, P., Trans). Princeton, NJ: Princeton University Press. (Original work published 1832-1834).

Whittaker, D. J. (2003). The Terrorism Reader. London: Routledge.

\section{Appendices}

\section{Appendix 1: Complete list of Bashar al-Assad's interviews used}

Al-Manar TV. (2013, May 30). Interview with Syrian President Bashar al-Assad. Lebanon. English dubbed video recording and transcript translated from Arabic into English retrieved on December 12, 2013 from http://www.globalresearch.ca/president-bashar-al-assad-full-interview/5337030 


\section{Journal of Terrorism Research}

CBS News. (2013, September 8). Charlie Rose interviews Syria’s President Bashar Assad. USA. Video recording and transcript retrieved on December 11, 2013 from http://www.cbsnews.com/news/exclusive-charlie-roseinterviews-syrias-president-bashar-assad-full-interview/

CCTV. (2013, September 24). Interview with Syrian President Bashar al-Assad. China. Transcript translated from Arabic into English retrieved on December 12, 2013 from http://syria360.wordpress.com/2013/09/23/ president-assads-interview-with-cctv-september-23-2013/

Der Spiegel. (2013, October 7). Interview with Bashar Assad: In the End, a Lie is a Lie. Germany. Transcript retrieved on December 12, 2013 from http://www.spiegel.de/international/world/spiegel-interview-withsyrian-president-bashar-assad-a-926456.html

Fox News. (2013, September 17). Interview with Syrian President Bashar al-Assad. USA. Video recording and transcript retrieved on December 12, 2013 from http://www.globalresearch.ca/president-bashar-al-assadsinterview-on-syrias-chemical-weapons-transcript/5350429

Frankfurter Allgemeine Zeitung. (2013, June 17). F.A.Z.-Interview with Bashar al-Assad: "Europe's backyard would become a terrorist haven". Germany. Transcript retrieved on December 12, 2013 from http://www.faz. net/aktuell/politik/ausland/naher-osten/f-a-z-interview-with-bashar-al-assad-europe-s-backyard-wouldbecome-a-terrorist-haven-12225367.html

Le Figaro. (2013, September 7). Interview with Syrian President Bashar al-Assad. France. Transcript retrieved on December 12, 2013 from http://syria360.wordpress.com/2013/09/03/president-assads-interview-with-lefigaro/

Rai News 24. (2013, September 29). Syria President al-Assad Interview: "We focus today on getting rid of terrorists and their ideology". Italy. Video recording retrieved on December 12, 2013 from http://www. youtube.com/watch?v=O1RTOPkNOkI

Transcript retrieved on December 12, 2013 from http://www.globalresearch.ca/president-al-assad-interviewwe-focus-today-on-getting-rid-of-terrorists-and-their-ideology/5352063

RT News. (2013, November 11). I'm not Western puppet - I live and die in Syria. Russia. Video recording retrieved on December 12, 2013 from http://www.youtube.com/watch?v=pdH4JKjVRyA

Transcript retrieved on December 12, 2013 from http://rt.com/news/assad-interview-exclusive-syria-265/

Russia 24 TV. (2013, September 24). Interview with Syrian President Bashar al-Assad. Russia. Transcript translated into English retrieved on December 12, 2013 from http://www.globalresearch.ca/syria-presidentbashar-al-assad-interview-on-chemical-weapons/5349664

Sunday Times. (2013, March 3). Interview with Syrian President Bashar al-Assad.United Kingdom. Transcript retrieved on December 13, 2013 from

http://syria360.wordpress.com/2013/03/03/president-assads-interview-with-sunday-times/

Tele SUR. (2013, September 25). President Al-Assad interview with teleSUR TV: US Policy has been based on Lies since the beginning. Venezuela. Transcript translated from Spanish into English retrieved on December 12, 2013 from http://www.globalresearch.ca/president-al-assad-interview-with-telesur-tv-us-policy-hasbeen-based-on-lies-since-the-beginning/5351660

Ulusal Kanal. (2013 April 5). Bashar Al Assad Interview: "Foreign Powers are Supporting the Entry of Terrorists in Syria". Turkey. English dubbed video recording retrieved on December 12, 2013 from http:// 
The Centre for the Study of Terrorism and Political Violence

\section{Journal of Terrorism Research}

www.globalresearch.ca/bashar-al-assad-interview-foreign-powers-are-supporting-the-entry-of-terrorists-insyria/5330089

Transcript translated into English retrieved on December 12, 2013 from http://syria360.wordpress. com/2013/04/05/president-bashar-al-assads-full-interview-with-turkish-tv/ 
The Centre for the Study of Terrorism and Political Violence

\section{Journal of Terrorism Research}

\section{Appendix 2: From Basic to Organizing to Global Themes}

\begin{tabular}{|c|c|c|}
\hline Basic themes & Organizing themes & Global theme \\
\hline Foreign support & \multirow[t]{4}{*}{ Terrorists operating in Syria } & \multirow[t]{10}{*}{$\begin{array}{l}\text { Syrian opposition as framed } \\
\text { by President Al-Assad }\end{array}$} \\
\hline Foreign fighters & & \\
\hline $\begin{array}{l}\text { Heterogeneous, but majority } \\
\text { is Al-Qaeda }\end{array}$ & & \\
\hline $\begin{array}{l}\text { Responsible for all human } \\
\text { suffering and atrocities }\end{array}$ & & \\
\hline $\begin{array}{l}\text { Dependant on foreign } \\
\text { countries }\end{array}$ & \multirow[t]{4}{*}{ Political opposition abroad } & \\
\hline Fabricated abroad & & \\
\hline $\begin{array}{l}\text { Does not represent Syrian } \\
\text { People }\end{array}$ & & \\
\hline Not united & & \\
\hline $\begin{array}{l}\text { Against terrorism and } \\
\text { supporting government }\end{array}$ & \multirow[t]{2}{*}{$\begin{array}{l}\text { Political (unarmed) } \\
\text { opposition in Syria }\end{array}$} & \\
\hline $\begin{array}{l}\text { Representing small parts of } \\
\text { Syrian population }\end{array}$ & & \\
\hline
\end{tabular}

